Prepared in cooperation with the U.S. Fish and Wildlife Service

\title{
Red-throated Loon (Gavia stellata) Use of Nearshore Marine Habitats-Results from a 2019 Pilot Study in Northern Alaska
}

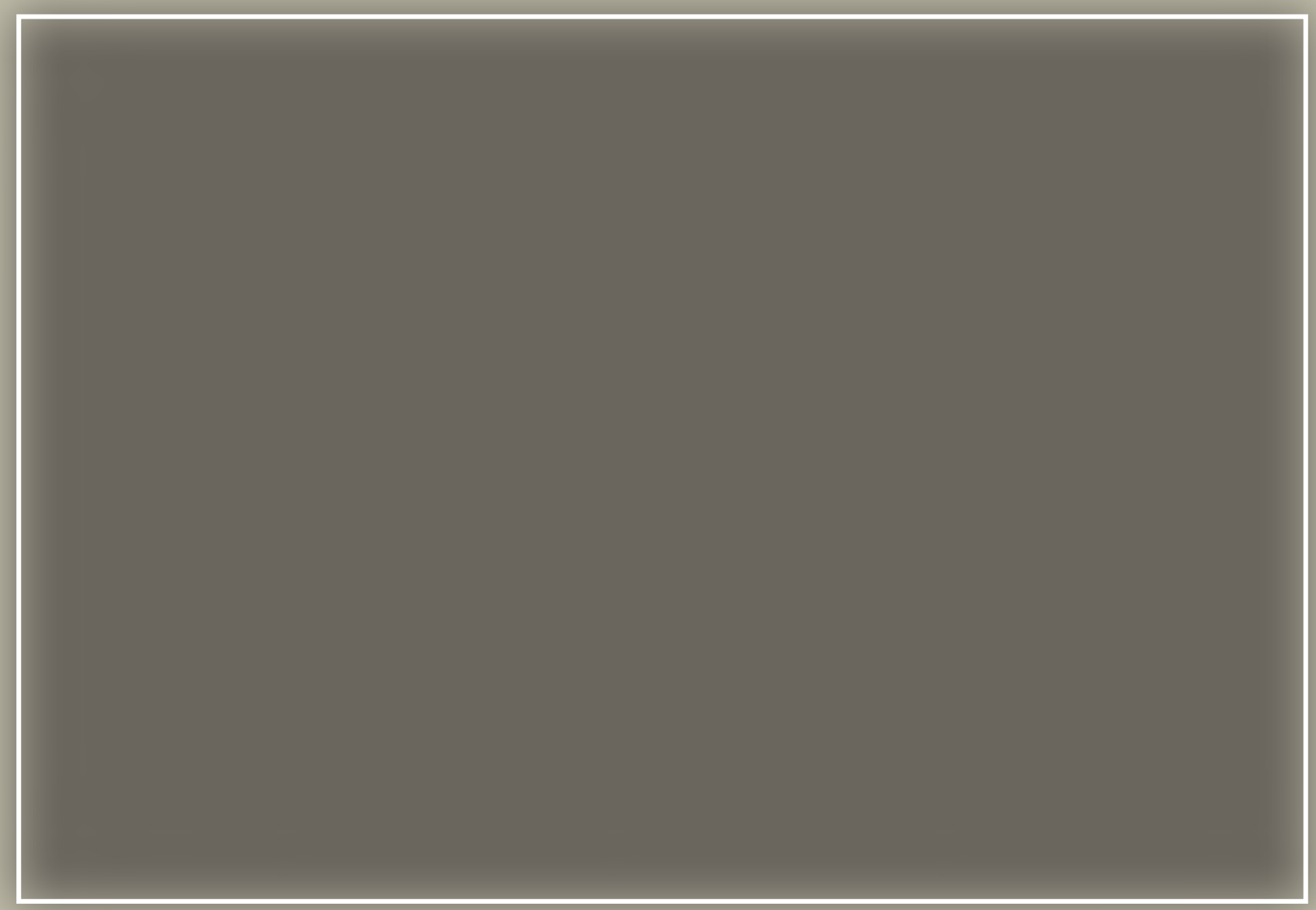

Open-File Report 2021-1029 
Cover: An adult red-throated loon (Gavia stellata) on its breeding lake in northern Alaska. Photograph by Ryan Askren, USGS Alaska Science Center. 


\section{Red-throated Loon (Gavia stellata) Use of Nearshore Marine Habitats-Results from a 2019 Pilot Study in Northern Alaska}

By Brian D. Uher-Koch, Christopher J. Latty, and Joel A. Schmutz

Prepared in cooperation with the U.S. Fish and Wildlife Service

Open-File Report 2021-1029 


\section{U.S. Geological Survey, Reston, Virginia: 2021}

For more information on the USGS - the Federal source for science about the Earth, its natural and living resources, natural hazards, and the environment-visit https://www.usgs.gov or call 1-888-ASK-USGS.

For an overview of USGS information products, including maps, imagery, and publications, visit https://store.usgs.gov/.

Any use of trade, firm, or product names is for descriptive purposes only and does not imply endorsement by the U.S. Government.

Although this information product, for the most part, is in the public domain, it also may contain copyrighted materials as noted in the text. Permission to reproduce copyrighted items must be secured from the copyright owner.

Suggested citation:

Uher-Koch, B.D., Latty, C.J., and Schmutz, J.A., 2021, Red-throated loon (Gavia stellata) use of nearshore marine habitats—Results from a 2019 pilot study in Northern Alaska: U.S. Geological Survey Open-File Report 2021-1029, 4 p., https://doi.org/10.3133/ofr20211029.

ISSN 2331-1258 (online) 


\section{Acknowledgments}

We thank Jakob Sipary (Alaska Native Science and Engineering Program) for field assistance. This project was supported by the USGS Changing Arctic Ecosystems Initiative and the Bureau of Ocean Energy Management. We thank Richard Raymond (Bureau of Ocean Energy Management), Cathy Coon (Bureau of Ocean Energy Management), and Vanessa von Biela (USGS Alaska Science Center) for discussions on this project. John Pearce, Matthew Smith, and Emily Weiser (USGS Alaska Science Center) provided helpful comments to prior versions of the manuscript. All capture and handling procedures were reviewed and approved by the USGS Alaska Science Center Animal Care and Use Committee (permit number 2019-06). Any use of trade, firm, or product names is for descriptive purposes only and does not imply endorsement by the U.S. Government. 


\section{Contents}

Abstract

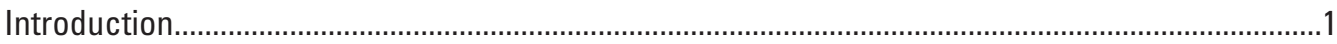

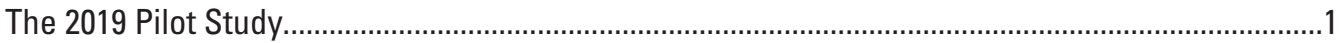

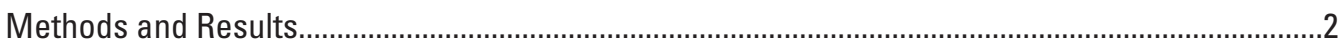

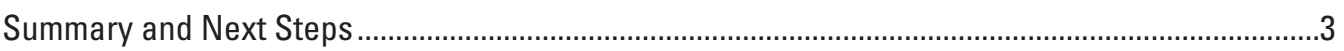

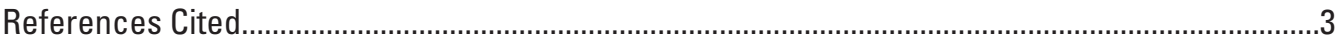

\section{Figure}

1. Map of GPS locations of one adult breeding red-throated loon (Gavia stellata) near the Canning River Delta in northern Alaska.

\section{Conversion Factors}

U.S. customary units to International System of Units

\begin{tabular}{lll}
\hline \multicolumn{1}{c}{ Multiply } & By & \multicolumn{1}{c}{ To obtain } \\
\hline foot $(\mathrm{ft})$ & Length & \\
mile $(\mathrm{mi})$ & 0.3048 & meter $(\mathrm{m})$ \\
& 1.609 & kilometer $(\mathrm{km})$ \\
\hline square mile $\left(\mathrm{mi}^{2}\right)$ & Area & \\
\hline & 2.590 & square kilometer $\left(\mathrm{km}^{2}\right)$ \\
\hline cubic foot per second $(\mathrm{ft} 3 / \mathrm{s})$ & Flow rate & \\
\hline
\end{tabular}

International System of Units to U.S. customary units

\begin{tabular}{|c|c|c|}
\hline Multiply & By & To obtain \\
\hline \multicolumn{3}{|c|}{ Length } \\
\hline meter $(\mathrm{m})$ & 3.281 & foot $(\mathrm{ft})$ \\
\hline meter $(\mathrm{m})$ & 1.094 & yard (yd) \\
\hline kilometer (km) & 0.6214 & mile (mi) \\
\hline kilometer $(\mathrm{km})$ & 0.5400 & mile, nautical (nmi) \\
\hline \multicolumn{3}{|c|}{ Area } \\
\hline square kilometer $\left(\mathrm{km}^{2}\right)$ & 0.3861 & square mile $\left(\mathrm{mi}^{2}\right)$ \\
\hline \multicolumn{3}{|c|}{ Flow rate } \\
\hline meter per year (m/yr) & 3.281 & foot per year ft/yr) \\
\hline
\end{tabular}

Temperature in degrees Celsius $\left({ }^{\circ} \mathrm{C}\right)$ may be converted to degrees Fahrenheit $\left({ }^{\circ} \mathrm{F}\right)$ as follows:

$$
{ }^{\circ} \mathrm{F}=\left(1.8 \times{ }^{\circ} \mathrm{C}\right)+32
$$




\title{
Red-throated Loon (Gavia stellata) Use of Nearshore Marine Habitats—Results from a 2019 Pilot Study in Northern Alaska
}

\author{
By Brian D. Uher-Koch¹, Christopher J. Latty², and Joel A. Schmutz ${ }^{1}$
}

\section{Abstract}

Red-throated loons (Gavia stellata) are a species of conservation concern in Alaska due to recent evidence of a population decline on the Arctic Coastal Plain (ACP) in northern Alaska. In 2019, the U.S. Geological Survey and the U.S. Fish and Wildlife Service conducted a pilot study to evaluate diet and use of nearshore foraging areas as possible drivers of the population decline. We collected fat biopsies to examine diet of breeding red-throated loons using previously outlined methods. We also deployed GPS-Ultra High Frequency transmitters on red-throated loons for an initial understanding of detailed offshore marine habitat use during the breeding season. A broader research project on marine habitat use and fish diet of breeding red-throated loons will begin in 2021 on the Canning River Delta and in Foggy Island Bay, Alaska.

\section{Introduction}

Red-throated loons (Gavia stellata) are a species of conservation concern in Alaska due to recent evidence of a decline in the population breeding on the Arctic Coastal Plain (ACP) in northern Alaska (Wilson and others, 2018; Amundson and others, 2019). Concurrently, populations of two sympatric loon species, the yellow-billed loon (G. adamsii) and Pacific loon (G. pacifica), are either stable or increasing on the ACP (Wilson and others, 2018; Amundson and others, 2019), highlighting the need to determine specific drivers of the population decline in red-throated loons. Because red-throated loons are sensitive to changing marine conditions and have high survival rates (Schmutz, 2014), it is important to determine the factors influencing reproductive success. One possible driver of low productivity includes changes in marine ecosystem forage conditions.

${ }^{1}$ U.S. Geological Survey Alaska Science Center, Anchorage, Alaska

2U.S. Fish and Wildlife Service, Arctic National Wildlife Refuge, Fairbanks, Alaska
Red-throated loons nest on freshwater lakes but primarily rely on marine fish prey to feed themselves and their chicks, unlike sympatric yellow-billed and Pacific loons which typically rely on freshwater fish and invertebrates for prey (Reimchen and Douglas, 1984; Eriksson and others, 1990; Uher-Koch and others, 2014). Thus, changes in nearshore fish communities may contribute to population decline of red-throated loons due to habitat deterioration or if preferred prey are less abundant or of lower quality (Dickson, 1992). Ongoing research has revealed long-term shifts in Beaufort Sea fish community composition and catch rates (Green and others, 2019), which has the potential to limit red-throated loons' ability to meet energetic needs during incubation and chick rearing. Therefore, identifying fine-scale habitat use, estimating loon energetic costs of flight and diving (for example, flying to/from marine foraging areas or during foraging bouts), and examining their diet will allow assessment of how marine conditions impact loon breeding success. To reduce uncertainty about possible drivers of the population decline of red-throated loons on the ACP, and to inform oil and gas exploration and development in onshore and offshore areas of northern Alaska, the Bureau of Ocean Energy Management prioritized an understanding of red-throated loon habitat in the nearshore marine environment of northern Alaska in 2020 (Bureau of Ocean Energy Management, 2019).

\section{The 2019 Pilot Study}

In 2019, the U.S. Geological Survey and the U.S. Fish and Wildlife Service conducted a pilot study on the Canning River Delta on the western coastal plain of the Arctic National Wildlife Refuge to evaluate the site and field protocols for future work. Specifically, the pilot study began efforts to evaluate marine habitat use by this species through deployment of GPS tags. The specific pilot study objectives were to:

1. Collect fat biopsy samples from adult red-throated loons for fatty acid analyses to identify prey types consumed during nesting and chick-rearing. 
2. Deploy GPS-Ultra High Frequency (UHF) transmitters on adult red-throated loons to test the feasibility of this technique and obtain preliminary movement data to be used to design a larger study on the foraging locations and fine-scale habitat use by loons in the Beaufort Sea.

\section{Methods and Results}

From June 26 to 29, 2019, we searched areas on the Canning River Delta for loon nests. We captured four nesting adult red-throated loons using bow-net traps (Salyer, 1962).
We collected fat biopsies from captured loons to examine diet of breeding red-throated loons using previously outlined methods (Owen and others, 2010). We wanted to determine the effectiveness of the transmitters prior to a larger scale study, so we only deployed three glue-on GPS-UHF transmitters on adult red-throated loons. We only obtained fine-scale resolution data from one loon due to nest or base-station failure. Raw data locations show offshore foraging locations in the Beaufort Sea (fig. 1). In future work, transmitters will also log dive duration to determine energy expenditure of loons during foraging trips.

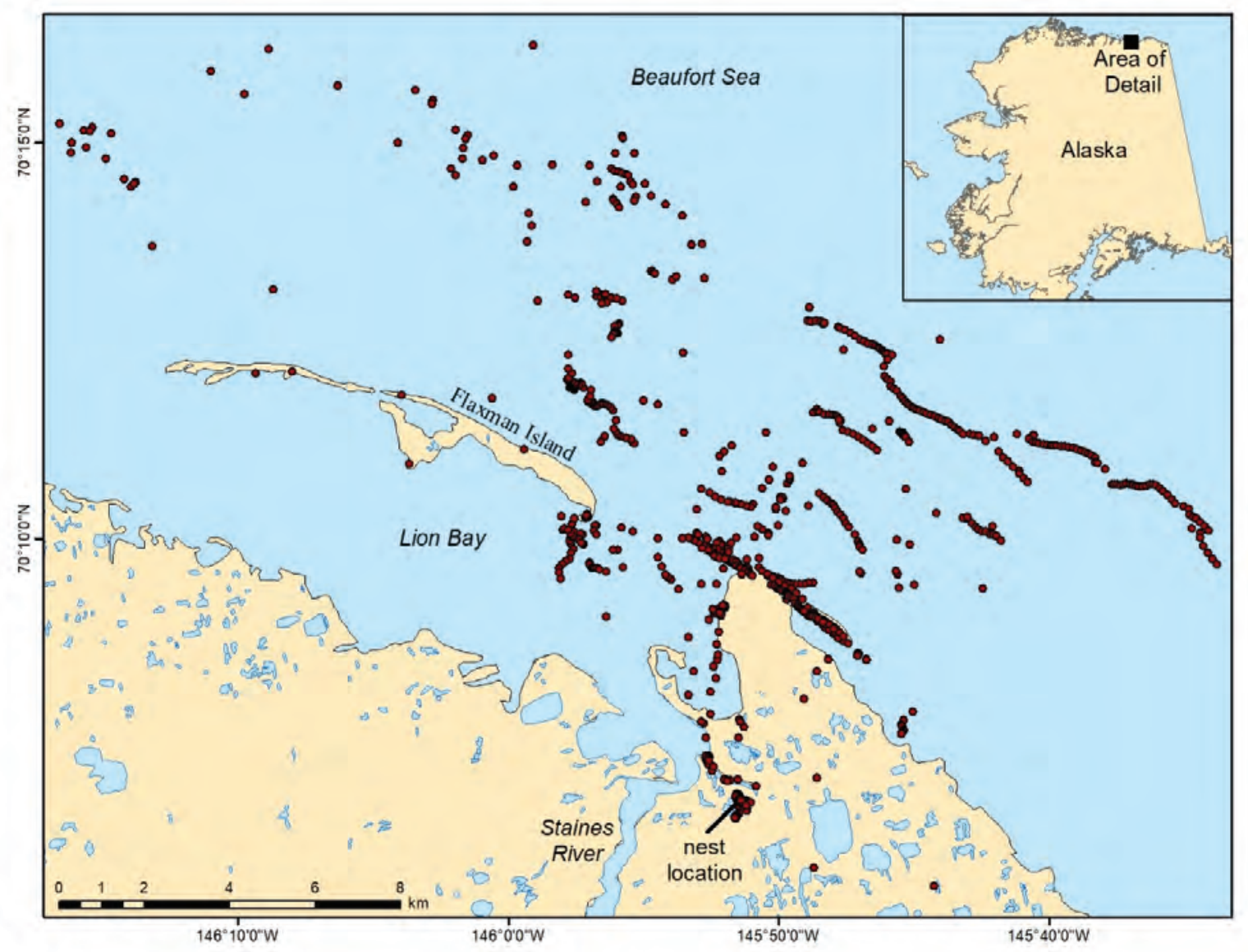

Figure 1. GPS locations (maroon dots) of one adult breeding red-throated loon (Gavia stellata) near the Canning River Delta in northern Alaska. GPS locations were collected approximately every 5 minutes from June 26 to July 13 , 2019 and have not been filtered. 


\section{Summary and Next Steps}

We plan to continue collecting data on breeding redthroated loons at the Canning River Delta during three field seasons, from 2021 to 2023. This effort will include deploying additional GPS transmitters. The addition of Global System for Mobile Communications (GSM) transmitting capabilities to these GPS transmitters in 2021 will improve data acquisition and increase sample size of marine locations. We also plan to deploy cameras at loon nests to identify nest fates and determine sources of nest failure (for example, predation).

Renewed interest in nearshore oil development and production in the Beaufort Sea has created a need to identify potential impacts on wildlife in the region. The proposed Liberty Development Project would include the construction of an artificial island in Foggy Island Bay (Hilcorp Alaska, 2017), an area likely used by breeding red-throated loons. We plan to add Foggy Island Bay, approximately $60 \mathrm{~km}$ to the west of the Canning River Delta, as a second coastal and nearshore marine study site in 2021. GPS locations from breeding loons in Foggy Island Bay area will be used to identify foraging locations and important marine habitats prior to industrial development.

This research is informed by ongoing and future nearshore fish community work in the Beaufort Sea that provides an understanding of spatial and temporal variation in relevant fish communities by revisiting historic sample sites. That project, "Nearshore fish surveys in the Beaufort Sea: Examining long-term community change and the role of nearshore habitats," is led by Vanessa von Biela (USGS Alaska Science Center) and will build upon existing datasets to inform our understanding of changes in fish species abundance, distribution, and species diversity along the coast of the ACP (Bureau of Ocean Energy Management, 2021). We plan to use this information to examine the relationship between fish prey abundance, fish energy density, and loon reproductive success.

\section{References Cited}

Amundson, C.L., Flint, P.L., Stehn, R.A., Platte, R.M., Wilson, H.M., Larned, W.W., and Fischer, J.B., 2019, Spatiotemporal population change of Arctic-breeding waterbirds on the Arctic Coastal Plain of Alaska: Avian Conservation \& Ecology, v. 14, no. 1, 198 p., https://doi.org/10.5751/ ACE-01383-140118

Bureau of Ocean Energy Management, 2019, Alaska Annual Studies Plan FY2020: U.S. Bureau of Ocean Energy Management, 231 p., accessed December 12th, 2019 at https:/www.boem.gov/sites/default/files/documents/ environment/2020-Studies-Plan.pdf.

Bureau of Ocean Energy Management, 2021, Environmental Studies Program: Ongoing Study, Nearshore fish surveys in the Beaufort Sea, Bureau of Ocean Energy Management, 3 p., accessed February 2, 2021 at https://www.boem.gov/ sites/default/files/documents/newsroom/BIO_AK-17x11_1.pdf.

Dickson, D.L., 1992, The red-throated loon as an indicator of environmental quality: Canadian Wildlife Service Occasional Paper 73, 17 p., accessed December 12th, 2019 at http://publications.gc.ca/site/eng/9.856012/ publication.html.

Eriksson, M.O.G., Blomqvist, D., Hake, M., and Johansson, O.C., 1990, Parental feeding in the red-throated diver Gavia stellata: The Ibis, v. 132, no. 1, p. 1-13, https://doi.org/ 10.1111/j.1474-919X.1990.tb01010.x.

Green, D.G., Priest, J.T., Gatt, K.P., and Sutton, T.M., 2019, Beaufort Sea nearshore fish monitoring study - 2018 annual report: Report for Hilcorp Alaska L.L.C. by the Fairbanks, Alaska, University of Alaska Fairbanks, College of Fisheries and Ocean Sciences, 93 p., accessed December 11th, 2020 at http:/www.north-slope.org/assets/ images/uploads/2018_Beaufort_Sea_Nearshore_Fish_ Monitoring_Annual_Report.pdf. 
Hilcorp Alaska, L.L.C., 2017, Liberty Development Project, Development and Production Plan: Amendment 3, Bureau of Ocean and Energy Management Alaska Outer Continental Shelf Region, https:/www.boem.gov/sites/ default/files/about-boem/BOEM-Regions/Alaska-Region/ Leasing-and-Plans/Plans/LIBERTY_DPP_amendment-305.26.17.pdf.

Owen, E., Daunt, F., and Wanless, S., 2010, Sampling avian adipose tissue-Assessing a nondestructive biopsy technique: Journal of Field Ornithology, v. 81, no. 1, p. 92-98, https://doi.org/10.1111/j.1557-9263.2009.00265.x.

Reimchen, T.E., and Douglas, S., 1984, Feeding schedules and daily food consumption in red-throated loons over the prefledging period: The Auk, v. 101, no. 3, p. 593-599, https://doi.org/10.1093/auk/101.3.593.

Salyer, J.W., 1962, A bow-net trap for ducks: The Journal of Wildlife Management, v. 54, p. 627-628.
Schmutz, J.A., 2014, Survival of adult red-throated loons (Gavia stellata) may be linked to marine conditions: Waterbirds, v. 37, sp1, p. 118-124, https://doi.org/10.1675/ 063.037.sp114.

Uher-Koch, B.D., Schmutz, J.A., Whalen, M., and Pearce, J.M., 2014, Changing Arctic ecosystems-Ecology of loons in a changing Arctic: U.S. Geological Survey Fact Sheet 2014-3093, 2 p., https://doi.org/10.3133/fs20143093.

Wilson, H.M., Larned, W.W., and Swaim, M.A., 2018, Abundance and trends of waterbird breeding populations on the Arctic Coastal Plain, Alaska, 1986-2017: U.S. Fish and Wildlife Service, Migratory Bird Management Unpublished Report, 47 p., accessed December 12th, 2019 at https://www.fws.gov/r7/mbsp/mbm/waterfowl/surveys/ pdf/2014-2017_ACP_Breeding_Pair.pdf. 
Publishing support provided by the U.S. Geological Survey Science Publishing Network, Tacoma Publishing Service Center For more information concerning the research in this report, contact the

Director, Alaska Science Center

U.S. Geological Survey

4210 University Drive

Anchorage, Alaska 99508

https://www.usgs.gov/centers/asc/ 


\section{एँ}

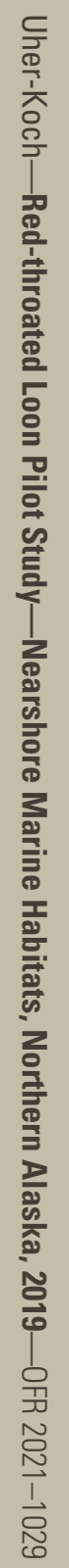

